ROCZNIKI PEDAGOGICZNE

Tom 12(48), numer $1-2020$

DOI: http://dx.doi.org/10.18290/rped20121-9

RYSZARD POLAK

\title{
WYCHOWANIE SPOŁECZNE W UJĘCIU JACKA WORONIECKIEGO UWAGI WSTĘPNE
}

Problematyka wychowania społecznego obecna jest niemalże we wszystkich dziełach J. Woronieckiego. Oczywiście najważniejszym z nich jest $\mathrm{Ka}$ tolicka etyka wychowawcza, ale i inne jego pisma, także te pozostające dotychczas w rękopisach lub maszynopisach, również zawierają interesujące nas tutaj treści. Polski dominikanin uważał, że wychowanie społeczne jest niezwykle ważne dla każdego narodu, ale w szczególności dla społeczeństwa polskiego, które przed $1918 \mathrm{r}$. przez ponad 120 lat nie miało niepodległego państwa, a swoją aktywność w dziedzinie polityki bieżącej skupiało głównie w tym tak długim czasie na walce z zaborcami, nie zaś na budowaniu silnej kulturowo, politycznie i gospodarczo oraz moralnie Rzeczypospolitej. Wpłynęło to w dużej mierze na naszą narodową mentalność, która stała się jakby bardziej indywidualistyczna niż w poprzednich epokach historycznych. Stąd też zaistniała, zdaniem uczonego, konieczność większego skupienia uwagi polskich pedagogów na takim wychowaniu dzieci i młodzieży, które skłaniałoby ludzi młodych do naturalnej, spontanicznej troski o dobro wspólne zmartwychwstałej na nowo ojczyzny. Wydaje się, że podjęcie się przedstawienia poglądów Woronieckiego na wychowanie w XXI wieku jest konieczne, ponieważ jego postulaty, a przede wszystkim podstawy filozoficzne, na jakich oparł on swoją pedagogiczną doktrynę, nie straciły do dzisiaj aktualności; wprost przeciwnie - powinno się je stale przypominać, ponieważ, jak się wydaje, kryzys moralny współczesnego nam społeczeństwa oraz zauważalny upadek kultury i dobrych obyczajów są wynikiem odejścia

Dr hab. RYSZARD POLAK, prof. AWF - Wydział Wychowania Fizycznego i Zdrowia Zakład Nauk Humanistyczno-Społecznych, Akademia Wychowania Fizycznego Józefa Piłsudskiego w Warszawie Filia w Białej Podlaskiej, , adres do korespondencji: ul. Akademicka 2, 21-500 Biała Podlaska; e-mail: ryszardpolak-ap@o2.pl; ORCID: https://orcid.org/0000-0002-5617-2333. 
od klasycznej, opartej na bogatej katolickiej tradycji koncepcji wychowania społecznego, jaką prezentował dominikanin. Stąd też pedagogika polska i europejska muszą skorzystać $z$ inspiracji wybitnych uczonych, w tym także Woronieckiego, aby ten destruktywny proces powstrzymać. Zadaniem autora niniejszego artykułu jest zainspirowanie współczesnych nam pedagogów, aby zdecydowali się na podjęcie pogłębionych studiów nad wychowaniem społecznym dzieci i młodzieży, opierając się na dorobku uczonego.

Zainteresowanie autora Katolickiej etyki wychowawczej wychowaniem społecznym miało i ma również inne, niż zasygnalizowano powyżej, historyczne i polityczne podłoże. Otóż warto zaznaczyć, że w czasach Woronieckiego dominowały w Polsce dwa nurty w filozofii społecznej i w pedagogice, które były z kolei konsekwencją upowszechnienia się dwóch odmiennych nurtów filozoficznego myślenia: indywidualizmu i kolektywizmu (Czupryn, 1999, s. 25). Doktryny te odrzucały katolicką koncepcję dobra wspólnego, prowadząc w konsekwencji bądź to do anarchizmu, bądź też do omnipotencji państwa, czego rezultatem było powstanie marksistowskiego komunizmu i niemieckiego narodowego socjalizmu. Szczególnie groźny dla kondycji moralnej człowieka był indywidualizm, który w skrajnych przypadkach powodował reakcję wprost przeciwną - utopijne marzenia wielu ludzi o socjalistycznym raju, będącym niejako swoistym remedium na zło indywidualistycznego liberalizmu (Woroniecki, 1986, t. 1, s. 30). Wspomniane nurty myślenia daje się zauważyć także we współczesnej nam pedagogice, zwłaszcza społecznej.

Walka z indywidualizmem i kolektywizmem, według polskiego myśliciela, powinna polegać przede wszystkim w praktyce na kształtowaniu cnót społecznych człowieka, zwłaszcza tych, które mają związek z cnotą sprawiedliwości. Sprawiedliwość zaś powinna być właściwie rozumiana - jako jedna $\mathrm{z}$ czterech cnót kardynalnych, dzięki której człowiek oddaje innym ludziom (także sobie) to, co się im słusznie należy. Znaczenie zaś tego, co jest „słuszne” i co się „należy” było i jest oczywiście różnie współcześnie pojmowane. Według Woronieckiego nie należy tych pojęć określać tak, jak czynili to liberałowie oraz socjaliści, którzy odeszli zupełnie od klasycznej aretologii, kwestionując jej założenia i zasady (Polak, 2017, s. 363-376). Ponadto cnota sprawiedliwości musi być w relacjach między ludźmi uzupełniana przez miłość, która jako cnota wlana (teologalna) skłania do większego poświęcenia się dla dobra innych osób i społeczeństwa (Woroniecki, 1939, s. 35, 49; Polak, 2018, s. 39-78). Dzięki miłości człowiek może realizować wielkie dzieła, takie, których nie dałoby się dokonać stosując zasady literalnie, 
„prawniczo” pojmowanej sprawiedliwości (Wistuba, 2011, s. 314). Ten aspekt filozofii społecznej dominikanina wydaje się we współczesnych nam czasach zapomniany i również jest godny zasygnalizowania.

Sprawiedliwość i jej realizowanie w życiu codziennym wiąże się z osobistym zaangażowaniem człowieka, poświęceniem i ofiarnością. Zdaniem Woronieckiego wiele dzieł o wielkiej i nieprzemijającej wartości powstało dzięki bezinteresownej pracy i nakładom ludzi odczuwających potrzebę brania udziału w życiu społecznym i pomocy innym członkom społeczeństwa, a więc dzięki ofiarności społecznej.

Wiemy dobrze, co kultura całego świata od wieków zawdzięcza prywatnej ofiarności, wiemy jak i dziś jeszcze przyczynia się ona do powstawania najdonioślejszych instytucji lub najcenniejszych dzieł sztuki. I dzieje się to nie tylko w bogatych społeczeństwach, ale i w ubogich, ma się rozumieć wedle tego, na co je stać. Pielęgnowanie tego ducha ofiarności na cele publiczne w ubogich jest ważniejsze niż w zamożnych (Woroniecki, maszynopis a, s. 59).

Ofiarność i dobroczynność społeczna powinny być dobrze zorganizowane i przemyślane przez lokalnych działaczy, ponieważ różnego rodzaju organizacje społeczne i organa władzy lokalnej mają o wiele większą orientację, jakiej pomocy i komu należy jej udzielać. Największym sprawdzianem skuteczności dobroczynności i ofiarności realizowanej przez prywatne osoby i samorządy są np. klęski żywiołowe. Wtedy to poszkodowanym należy szybko udzielać wszechstronnej pomocy, ponieważ zwykle jest tak, że w budżetach państwowych nie ma przewidzianych dostatecznych środków na ten cel (wydatki bieżące związane są bowiem z funkcjonowaniem państwa i pochłaniają znaczną część podatków płaconych przez ludność) (Woroniecki, maszynopis b, s. 4-5).

Zdaniem Woronieckiego, we współczesnych społeczeństwach ludzie powinni sami - nie oglądając się na instytucje państwowe - świadczyć między sobą różnego rodzaju usługi i udzielać pomocy, chociaż kierując się cnotą sprawiedliwości rozdzielczej - osoby dzierżące władzę państwową oczywiście mają obowiązek dbać o wszystkich, zwłaszcza tych, którym ze względu na różne przypadki losowe i okoliczności popadli w biedę.

Pomimo tego jednak, że organa państwowe w pierwszym rzędzie powołane są do zapobiegania nędzy i organizowania dobroczynności, to jednak akcja ich nigdy nie wystarcza na zaspokojenie wszystkich bied ludności; współdziałanie dobroczynności prywatnej we wszystkich państwach, nawet tych, gdzie dobroczynność publiczna jest najlepiej zorganizowana, okazuje się zawsze konieczne (Woroniecki, maszynopis b, s. 3). 
Dlatego też wychowanie społeczeństwa jest $\mathrm{w}$ tym kierunku niezwykle potrzebne, bowiem dzięki niemu wzrasta poziom ofiarności publicznej oraz różnicują się jego formy.

Ofiarność społeczna, praktykowana powszechnie w starożytności i w średniowieczu, zdaniem Woronieckiego zaczęła zanikać wraz z upowszechnieniem się w Europie opartego na egoistycznej wizji człowieka liberalizmu oraz przeciwnego mu etatyzmu, krępującego swobodę działania ludzi w sferze gospodarczej poprzez narzucanie przez władzę państwową ustawodawstwa o charakterze socjalistycznym (Woroniecki, 1986, t. 2/2, s. 370; Woroniecki, 1935, s. 240). Stąd też istnieje konieczność jej kultywowania w nowej, dostosowanej do wymogów czasów formie.

Dominikanin pisał w związku z tym, że pod naporem wspomnianych ideologii indywidualizmu i kolektywizmu

Zatraciliśmy starą tradycję fundacji dobroczynnych opartą na zasadach miłosierdzia chrześcijańskiego, zastąpiliśmy ją opieką społeczną, łudząc się, że te niezliczone potrzeby rzesz upośledzonych dadzą się zaspokoić przez urzędników przez okienka w ich biurach (Woroniecki, 1925, s. 208).

Dlatego też należy walczyć z ideologiami - zarówno liberalną, jak i socjalistyczną, bo jeśli tego nie będziemy czynić, to będą one negatywnie oddziaływały na nasze życie i mentalność, przyczyniając się do tego, że nasza wrażliwość na krzywdy materialne i moralne innych ludzi będzie stawała się coraz to mniejsza. Ponieważ zarówno kolektywistyczny socjalizm, jak też i liberalizm są nadal ideologiami dominującymi we współczesnym świecie, należy koniecznie przestrzegać pedagogów przed ich niekiedy entuzjastycznym akceptowaniem, mając w pamięci to, co na ten temat głosił Woroniecki.

\section{WSPÓLNOTY LUDZKIE A WYCHOWANIE CZŁOWIEKA}

Zdaniem Woronieckiego człowiek, jako osoba mogąca w pełni żyć i rozwijać się zgodnie ze swoją naturą, musi pozostawać we właściwych relacjach $\mathrm{z}$ innymi ludźmi i stale $\mathrm{z}$ nimi współpracować, ponieważ tylko w ten sposób może zrealizować swoje najbardziej zaszczytne, dobre cele (Gałkowski, 2003, s. 49). Także i społeczności ludzkie, istniejące istnieniem osób i różnorodnych relacji oraz zależności między poszczególnymi jednostkami, wywierają wszechstronny, również wychowawczy, wpływ na każdego pojedynczego człowieka (Horowski, 2007, s. 191). Najlepszym i najwartościowszym 
środowiskiem wychowawczym, w którym żyje i powinien się rozwijać każdy człowiek, jest rodzina, w dalszej kolejności różne funkcje wychowania społecznego przypadają w udziale Kościołowi katolickiemu, szkole i różnym organizacjom młodzieżowym (Mazur, Kiereś, Skrzyniarz, Płazińska, 2019, s. 71-73).

\section{RODZINA JAKO ŚRODOWISKO WYCHOWAWCZE}

W swojej Katolickiej etyce wychowawczej Woroniecki podkreślał, że rodzina jest podstawową komórką życia społecznego, w której człowiek uczy się już od chwili poczęcia życia wspólnotowego i praktycznej realizacji dobra wspólnego (Woroniecki, 1986, t. 2/2, s. 106). Człowiek, który rodzi się w niej, musi w niej być również wychowywany przez rodziców, którzy mogą robić to najlepiej, bowiem zwykle w sposób naturalny i spontaniczny obdarzają swoje potomstwo miłością i opieką. Jest tak dlatego, ponieważ - jak wiadomo - w przeciwieństwie do zwierząt ludzie od swego urodzenia posiadają wolną i rozumną wolę, która, aby nie uległa moralnej degradacji, od początku właściwie musi być przez rodziców kształtowana. A rodzice pragną przecież dla swoich dzieci dobra. Najpierw, w wieku najmłodszym, osoba ludzka jest otoczona szczególną troską rodziców, by potem coraz to bardziej samemu uczestniczyć w procesie swego wychowania (Woroniecki, 1986, t. 2/2, s. 106). Zdaniem Woronieckiego w trudnym dziele wychowania potomstwa mają obowiązek czynnie uczestniczyć oboje rodzice wraz z innymi domownikami, tworząc specyficzny, przyjazny klimat najbardziej odpowiedni do tego, aby zamierzony cel osiągnąć w sposób możliwie najdoskonalszy (Woroniecki, 1986, t.2/2, s. 116).

Przeciwny był Woroniecki poglądom wielu współczesnych mu ideologów, którzy żywili fałszywe przekonanie, że obowiązek wychowania dzieci mogą rodzice scedować na szkołę, której zadaniem miało być przede wszystkim ukształtowanie właściwej postawy moralnej uczniów, a w dalszej kolejności ich nauczanie (Kalinowska, 2000, s. 175). Uczony z ubolewaniem pisał:

Najpierw życie rodzinne u nas stoi na niskim poziomie, rodzice dziećmi zajmują się mało, i oddając je do szkoły, radzi by całkowicie zwalić na nią swe obowiązki wychowawcze. Tym się tłumaczy to ciągłe narzekanie na naszą szkołę, że uczy, a nie wychowuje. Zapewne, że szkoła zadań wychowawczych nigdy nie powinna tracić z oczu, zapewne, że mogłaby lepiej wypełniać niż to dziś robi, ale nie trzeba się łudzić, aby mogła ona zastąpić rodziców, nie trzeba przeceniać jej zdolności wychowawczych. Pierwszym zadaniem szkoły jest nauczanie, a wychowanie 
dopiero drugim; jest ona całkowicie odpowiedzialna za wykształcenie młodzieży, ale nie za wychowanie i choćby swe obowiązki w dziedzinie wychowania jak najlepiej spełniała, rezultaty będą żadne, o ile inne czynniki wychowawcze zawiodą (Woroniecki, 1918, s. 460-461).

Wychowanie dzieci w rodzinie służy nie tylko indywidualnym celom każdego pojedynczego człowieka, ale ma też wymiar społeczny (Woroniecki, 1935, s. 126). Dlatego też trwanie w monogamicznej rodzinie i kształtowanie postaw moralnych dzieci jest obowiązkiem każdego odpowiedzialnego rodzica i rozumnego członka społeczności państwowej i dobrego obywatela.

Podobnie jak wielu katolickich uczonych zajmujących się problematyką małżeństwa i rodziny, kryzysu małżeństwa dopatrywał się Woroniecki w szerzącym się od czasów nowożytnych indywidualizmie, a także w materialistycznym światopoglądzie, który zaczął już od XVIII stulecia dominować w mentalności jednostek żyjących w kręgu oddziaływań kultury Europy zachodniej, oraz będącego ich konsekwencją egoizmu. Indywidualistyczna postawa jednostek przyczyniała się zaś zawsze do negowania pierwszego i podstawowego celu, w którym zawierane było małżeństwo, tj. zrodzenie potomstwa i jego dobre wychowanie. Dominikanin twierdził, że to właśnie te zjawiska wpłynęły niezwykle negatywnie na ilość rozwodów i ograniczenie liczby rodzących się dzieci (Woroniecki, 1935, s. 113). Odegrały też znaczącą rolę w promulgowaniu we współczesnym ustawodawstwie liberalnego prawa małżeńskiego, które przestało już dostatecznie chronić rodzinę przed jej rozpadem i patologiami z tym związanymi, a sprzyjało jej rozkładowi. Brak zaś odpowiednich uregulowań prawnych chroniących dzieci przed zgubnymi skutkami ich wychowywania $\mathrm{w}$ rodzinach niepełnych spowodował, że kolejne pokolenia młodych ludzi stają się coraz to słabsze moralnie i narażone są na moralną degradację.

\section{KOŚCIÓŁ KATOLICKI JAKO WYCHOWAWCA DZIECI I MŁODZIEŻY}

Kościół katolicki jest także ważnym wychowawcą człowieka, zwłaszcza gdy weźmiemy pod uwagę nie tylko religijny, ale także społeczny wymiar jego działalności. Różnego rodzaju wspólnoty kościelne zawsze wspierały rozwój moralny swoich członków i zapobiegały szerzeniu się deprawacji moralnej. Woroniecki uważał, że zwłaszcza modlitwa wspólnotowa, której znaczenie tak bardzo podkreślał Jezus Chrystus w swoim ziemskim nauczaniu i która również obecnie jest praktykowana w Kościele katolickim, ma niezwykle istotną rolę w tym procesie (Kiereś, 2015, s. 137). 
Dominikanin był przekonany, że największe praktyczne znaczenie wychowawcze ma tutaj śpiew gregoriański (Woroniecki, 1916, s. 9; Boużyk, 2016, s. 357-373). Wypowiadając się na ten temat stwierdzał on między innymi, że

śpiew kościelny łączy w sobie dwa pierwiastki: modlitwę i muzykę. [...] w kościele śpiew gregoriański, to modlitwa śpiewana, zaś śpiew figuralny, to śpiew na temat modlitwy [...] W śpiewie gregoriańskim tekst modlitwy nie może ulec żadnej zmianie, ale zależnie od melodii śpiew poszczególnych sylab może być odpowiednio rozciągnięty. [...] Śpiew gregoriański nie daje sposobności do popisywania się wybitniejszymi zdolnościami muzykalnymi, to nie ulega wątpliwości, i tu tkwi racja, dlaczego wiele osób o większym uzdolnieniu muzycznym ma doń pewne uprzedzenia. [...] Ale na tym właśnie polega jego wartość wychowawcza, że żąda pewnego podporządkowania się całości i nie pozwala zbyt wyłącznie ściągać na siebie uwagi słuchaczy. [...] Msza święta śpiewana po gregoriańsku, to modlitwa całego zgromadzenia wiernych, słuchaczem jej jest jeden tylko Bóg, do którego się wznosi. Piękno jej na tym właśnie polega, że wszystkie głosy zlewają się w jedną potężną całość, w której śpiewu poszczególnych osób nie słychać, a tylko śpiew całości, świadczącej przed Bogiem, że są oni jedną duszą i jednym ciałem. I to jest właśnie tak ważne pod względem społecznym. Cała trudność pracy społecznej na tym najczęściej polega, że jednostka nie chce podporządkować się całości. [...] Otóż śpiew gregoriański takie odruchy indywidualizmu i takie wysuwanie siebie na pierwszy plan bardzo systematycznie niweluje. [...] Wytwarza się tą drogą pewne umiłowanie akcji wspólnej. [...] Nauczywszy się tego w murach świątyni, na służbie Bożej, łatwiej byłoby następnie i w życiu codziennym utrzymać na wodzy to pożądanie zwracania na siebie uwagi, o które tyle przedsięwzięć społecznych się rozbija (Woroniecki, 1930, s. 19).

Śpiew gregoriański cechuje się też dużą prostotą, jego melodia zaś szybko „wpada w ucho”, dzięki czemu większość wiernych Kościoła katolickiego chętnie uczestniczy w modlitwie doskonaląc, się moralnie (Woroniecki, 1986, t. 2/1, s. 319-320).

\section{WYCHOWANIE SPOŁECZNE W SZKOLE}

Szkoła jako instytucja jest również ważną instytucją wychowawczą (Kalinowska, 2005, s. 120-121). Jej oddziaływanie na dzieci i młodzież odbywa się poprzez pracę nauczycieli, którzy powinni cechować się szczególnymi cechami charakteru, takimi jak roztropność, w szczególności zaś jej istotny składnik - długomyślność, a także posiadać dużą wiedzę i umiejętność jej przekazywania oraz zainspirowania uczniów do samodzielnego wysiłku intelektualnego i systematycznej pracy (Woroniecki, 1930a, s. 187). 
Duże znaczenie mają także programy nauczania ustalone przez władze oświatowe i dobierane przez polonistów i nauczycieli innych przedmiotów, zwłaszcza humanistycznych.

Uczony zwracał uwagę na wpływ nauki języka ojczystego na kształtowanie woli wychowanków oraz na formowanie ich postaw patriotycznych (Woroniecki, 1929, s. 24; Stefaniak, 2015, s. 251-258). Uwzględnienie powyższego faktu powinno być, zdaniem Woronieckiego, motywem przewodnim działań pedagogicznych wszystkich nauczycieli (Woroniecki, 1924, s. 73). Powinni oni zdawać sobie sprawę z tego, że

przy nauce mowy ojczystej powinna się więc odbywać świadoma praca nad charakterem; przy opowiadaniach ustnych czy piśmiennych, przy wypracowaniach szkolnych czy domowych trzeba wymagać od ucznia tego wysiłku wewnętrznego, aby myśl dobrze oddawał, aby za pomocą mowy stał się panem swego wewnętrznego procesu myślowego (Woroniecki, 1925, s. 26).

Wzorem pisarza, który połączył swój geniusz literacki z pełnym zdroworozsądkowego realizmu patriotyzmem był zdaniem Woronieckiego Henryk Sienkiewicz, stąd też przede wszystkim jego dzieła należy polecać uczącej się młodzieży jako lektury obowiązkowe (Woroniecki, 1996, s. 265-270).

\section{UCZESTNICTWO UCZNIÓW W ŻYCIU SPOŁECZNYM SZKOŁY}

Aby młodzież mogła w pełni rozwijać swe potencjalne możliwości intelektualne i moralne, powinna ona - zdaniem dominikanina - aktywnie uczestniczyć w życiu szkoły poprzez angażowanie się w działalność w organizacjach społecznych i oświatowych działających na jej terenie.

Warto jednakże zaznaczyć, że jeśli chodzi o propagowanie idei wychowania społecznego, polski dominikanin zajmował stanowisko bardziej umiarkowane niż zwolennicy tzw. kolektywistycznej koncepcji (którzy przypisywali wychowaniu państwowemu oraz organizacjom społecznym młodzieży większe znaczenie niż rodzinie), chociaż niewątpliwie bardzo wspierał różnego rodzaju wspólnoty młodzieżowe i dziecięce, widząc w nich dużą przeciwwagę dla panoszącego się wszędzie indywidualizmu, wywierającego negatywny wpływ na dziedzinę wychowania człowieka (Woroniecki, 1921b, s. 24). Szczególnie cenne w dziele uspołeczniania dzieci i młodzieży są tutaj organizacje skautingowe i harcerskie, które są ,zorganizowaniem samowychowania młodzieży przez młodzież" (Woroniecki, 1918, s. 453; Winiarz, 
1994, s. 10-14) i uczą karności oraz posłuszeństwa i podejmowania różnych inicjatyw (Woroniecki, 1921a, s. 57-58; Błeszyńska, s. 108-111).

Również, jak twierdził Woroniecki, nawiązywanie wspólnych kontaktów koleżeńskich między dziećmi i młodzieżą, opartych na wzajemnej przyjaźni i współpracy jest często niezauważanym przez dorosłych, lecz bardzo istotnym czynnikiem wychowawczym (Woroniecki, 1921a, s. 57-58; Woroniecki, 1986, t. 2/2, s. 66). Uczony nie zgadzał się z opiniami niektórych współczesnych mu działaczy katolickich, którzy zarzucali ruchowi skautowemu i harcerskiemu propagowanie moralności „racjonalistycznej”, uznając, że są one absurdalne i pozbawione jakichkolwiek dowodów.

\section{UWAGI KOŃCOWE}

Jacka Woronieckiego nauka o wychowaniu społecznym człowieka miała doniosłe znaczenie dla polskiej pedagogiki okresu II Rzeczypospolitej, kiedy to jego dzieła i poglądy były powszechnie znane i omawiane, a sam ich autor brał bardzo czynny udział w ich propagowaniu, wykłaszając liczne wykłady naukowe i popularnonaukowe, rekolekcje i pogadanki dla młodzieży. Spotkały się one $\mathrm{z}$ bardzo życzliwym przyjęciem w polskim społeczeństwie, które po długim okresie niewoli narodowej budowało na nowo podstawy organizacyjne i ideowe polskiej oświaty. Niestety, po drugiej wojnie światowej jego nauczanie było ignorowane i świadomie przemilczane przez ideologów komunistycznych i dlatego między innymi osoba dominikanina została na długi czas zapomniana przez pedagogów.

Obecnie, kiedy istnieje możliwość swobodnego korzystania z prac Woronieckiego, a także ich ponownego publikowania oraz poddawania rzetelnej analizie naukowej, polscy uczeni znowu sięgają po jego dzieła. Jednak zdarza się niestety, że jego spuścizna jest czytana zbyt pobieżnie, co wynika jak się wydaje - z faktu, że zajmują się nią ludzie bez solidnego przygotowania filozoficznego i historycznego. Stąd też istnieje konieczność prowadzenia dalszych badań, mających charakter interdyscyplinarny i pogłębiony, dzięki którym postać tak wybitna, jak polski dominikanin, stanie się jeszcze bardziej znana. Jego zaś sugestie i porady dotyczące wychowania społecznego powinny być nie tylko omawiane teoretycznie, ale także praktycznie realizowane w dzisiejszych naszych czasach, bo są one wartościowe i ponadczasowe. 


\section{BIBLIOGRAFIA}

BŁeszYŃSKA, I.Z. (2006). O. Jacek Woroniecki - Dominikanin - Wychowawca - Patriota 18781949. Lublin: Instytut Edukacji Narodowej.

BoużYK, M.M. (2016). Jacek Woroniecki o modlitwie jako czynniku doskonalącym naturę ludzką. Rocznik Tomistyczny, 5, 357-373.

CZUPRYN, B. (1999). Antropologiczne podstawy teorii wychowania według Woronieckiego. Człowiek $w$ Kulturze, 12, 23-29.

GaŁKowski, S. (2003). Rozwój i odpowiedzialność. Antropologiczne podstawy koncepcji wychowania moralnego. Lublin: Wydawnictwo KUL.

Horowski, J. (2007). Paedagogia perennis w dobie postmodernizmu. Wychowawcze koncepcje o. J. Woronieckiego a kultura przełomu XX i XXI wieku. Toruń: Europejskie Centrum Edukacji.

KALINOwSKA, K. (2005). Jacek Woroniecki o społeczeństwie i państwie. Lublin: Wydawnictwo Servire Veritati Instytut Edukacji Narodowej.

KALINOwSKA, K. (2000). Wychowawcza funkcja rodziny w myśli Jacka Woronieckiego OP. W: J. GAŁKowsKi, M.L. NiedZIELA (red.), Człowiek - moralność - wychowanie. Życie i myśl Jacka Woronieckiego OP (s. 169-178). Lublin: Towarzystwo Naukowe KUL.

KIEREŚ, B. (2015). U podstaw pedagogiki personalistycznej. Filozoficzny kontekst sporu o wychowanie. Lublin: Polskie Towarzystwo Tomasza z Akwinu.

Mazur, P.S., Kiereś, B., Skrzyniarz, R., PŁazińSKA, A. (2019). Jacek Woroniecki. Kraków: Wydawnictwo Naukowe Akademii Ignatianum.

POLAK, R. (2017). Człowiek i moralność w myśli Jacka Woronieckiego. Filozoficzne podstawy katolickiej etyki wychowawczej i jej zasady. Warszawa-Radzymin: Wydawnictwo von boroviecky.

PolaK, R. (2018). Człowiek i religia w myśli Jacka Woronieckiego OP. Warszawa-Radzymin: Wydawnictwo von boroviecky.

STEFANIAK, Ł. (2015). Język ojczysty w mediach i jego oddziaływanie na kulturę narodową z perspektywy nauczania o. Jacka Woronieckiego. W: A. SugIER-SzEREGA (red.), Medialne reprezentacje kultury, literatura, teatr, sztuka i religia (s. 251-258). Lublin: Wydawnictwo KUL.

WiniARZ, A. (1994). Związek Harcerstwa Polskiego na Lubelszczyźnie 1918-1939. Lublin: Wydawnictwo UMCS.

Wistuba, G. (2011). Prowadzić ku Zbawcy. Duszpasterstwo w nauczaniu i postudze o. Jacka Woronieckiego OP. Sandomierz: Wydawnictwo Diecezjalne i Drukarnia w Sandomierzu.

Woroniecki, J. (1930a). Długomyślność jako właściwa cnota wychowawcy. Szkoła Chrystusowa, 1(4), 178-195.

Woroniecki, J. (1930b). Doniostość wychowawcza liturgii eucharystycznej. Kraków: „Mysterium Christi".

WoronieCKI, J. (1929). Gawęda o gawędzeniu. Poznań: Księgarnia św. Wojciecha.

WORONIECKI, J. (1986). Katolicka etyka wychowawcza, t. 1-2/2. Lublin: Redakcja Wydawnictw KUL.

WoronIECKI, J. (1925). Miłosierdzie i nasza na nie odpowiedź. Szkoła Chrystusowa, 11(11), 193-210.

WoronieCKi, J. (1918). O przyszłość ruchu skautowego w Polsce. Rok Polski, 3(7-8), 451-467.

WORONIECKI, J. (1925). Około kultu mowy ojczystej. Lwów-Warszawa: Książnica-Atlas.

WORONIECKI, J. (maszynopis a). Państwo i szkoła. Rozprawa z etatyzmem kulturalnym. Archiwum Polskiej Prowincji Dominikanów w Krakowie: sygn. VI 2100. 
Woroniecki, J. (1996). Pośmiertna misja Henryka Sienkiewicza. Przemówienie wygłoszone na inauguracji sali jego imienia na Uniwersytecie Lubelskim dnia 22 czerwca 1923 r. Człowiek w Kulturze, 8, 265-270.

Woroniecki, J. (1921a). Próba wartości harcerstwa. W: W. Niklewicz, S. Sedlaczek, H. Glass (red.), Na dalsza drogę. Uwagi i myśli o ruchu starszego harcerstwa (s. 56-63). Warszawa: Książnica Harcerstwa i Kultury Fizycznej.

WoronieCKI, J. (1939). Wiara, nadzieja i miłość w życiu Najświętszej Maryi Panny. Toruń: Instytut Różańcowy.

WoronieCKi, J. (1935). U podstaw kultury katolickiej. Poznań: Naczelny Instytut Akcji Katolickiej.

WORONIECKI, J. (1921b). Wychowanie społeczne i praca społeczna. Warszawa: [s.n.].

WORONIECKI, J. (maszynopis b). Zasady dobroczynności prywatnej i jej zadania w najbliższej przyszłości. Archiwum Polskiej Prowincji Dominikanów w Krakowie: sygn. Ao 948/f10.

WORONIECKI, J. (1924). Zdolność wychowawcza szkoły publicznej i jej granice. Miesięcznik Katechetyczny i Wychowawczy, 13(5-7), 69-75.

WoronieCKi, J. (1916). Z powodu ostatniego dzieła profesora Zdziechowskiego. Lwów: [s.n.].

\section{WYCHOWANIE SPOŁECZNE W UJĘCIU JACKA WORONIECKIEGO}

\section{STRESZCZENIE}

Zagadnienia związane z wychowaniem społecznym człowieka były szczególnym przedmiotem zainteresowania Jacka Woronieckiego jako uczonego i praktyka, który sam osobiście wielokrotnie miał okazję jako pedagog i duszpasterz wywierać wpływ na kształtowanie się charakterów i postaw moralnych dzieci oraz młodzieży. Stąd też polski dominikanin dużo miejsca poświęcał tej problematyce w swoich dziełach.

Woroniecki przeciwny był indywidualizmowi i kolektywizmowi - doktrynom, które jego zdaniem przesadnie interpretowały naturę człowieka. Pierwsza z nich - indywidualizm - bagatelizowała wychowanie społeczne ludzi, uznając, że człowiek jako egoista $z$ natury nigdy nie będzie w stanie przyjąc i zaakceptować norm i zasad moralnych narzuconych mu przez społeczeństwo. Dlatego indywidualiści uważali, że człowiek sam powinien przede wszystkim być panem swojego życia - nie oglądając się na społeczeństwo i obowiązujące w nim reguły postępowania. Druga z wymienionych doktryn - kolektywizm - zakładała, że narzucanie jednostkom norm postępowania obowiązujących w dużych grupach społecznych (np. narodzie lub państwie) przyczyni się na pewno do zachowania ładu i porządku społecznego, nawet wbrew dobru poszczególnych ludzi.

Dominikanin uważał, że walka z indywidualizmem i kolektywizmem musi polegać na wychowaniu człowieka do cnót moralnych, zarówno indywidualnych, jak i społecznych. Dzięki nim bowiem człowiek może właściwie funkcjonować w społeczeństwie i rozwijać swoje naturalne predyspozycje oraz skłonności, a także dobrze żyć jako osoba w pełni wolna i autonomiczna w swoim działaniu.

Dużo miejsca poświęcił Woroniecki w swoich dziełach cnocie sprawiedliwości, która przez wielu mu współczesnych myślicieli była fałszywie pojmowana, co było źródłem wielu społecznych konfliktów i nieporozumień. Uczony uważał, że należy powrócić do starożytnych i średniowiecznych (głównie scholastycznych i opartych na nauce św. Tomasza z Akwinu) koncepcji sprawiedliwości jako cnoty moralnej, polegającej na oddawaniu każdemu człowiekowi tego, co się mu słusznie należy. Do takiej postawy należy każdego człowieka wychowywać; nie da się 
bowiem sprowadzić postępowania sprawiedliwego do „mechanicznego” tylko przestrzegania prawa ustanowionego przez państwo. Każdy człowiek spontanicznie i bez żadnego zewnętrznego przymusu powinien dbać o dobro własne i innych ludzi, czyniąc to w sposób naturalny, ponieważ do tego typu zachowań ma być wychowany już od dzieciństwa.

Ludzie, według Woronieckiego, powinni być wychowywani do życia społecznego w naturalnych, potrzebnych im do dobrego funkcjonowania wspólnotach: rodzinie, Kościele katolickim oraz szkole, która ze względu na szybki rozwój nauki i oświaty odgrywa we współczesnym świecie coraz to większą rolę. Rodzina powinna mieć według Woronieckiego monogamiczny i trwały charakter, a jej rozwój i zadania wychowawcze powinny być wspomagane przez państwo i obowiązujące w nim stanowione prawo. Również Kościół katolicki, będący instytucją umożliwiającą duchowy rozwój człowieka, daje członkom swojej wspólnoty możliwość wzajemnego współdziałania i wspólnej pracy, a tym samym wychowywania się. Uczy również coraz rzadszej, ale cennej i godnej kultywowania cnoty pokory, a także systematyczności i wytrwałości w dążeniu do dobra.

Szkoła wychowuje człowieka dzięki nauczycielom i wychowawcom, którzy powinni być ludźmi moralnie dobrymi i wykształconymi, a także znającymi dobrze psychikę dziecka i prawa jego moralnego, intelektualnego i fizycznego rozwoju. Woroniecki przywiązywał dużą wagę do konieczności umiejętnego kształcenia uczniów w oparciu na dobrze przygotowanych uprzednio programach szkolnych oraz właściwie dobrane lektury. Ważną rolę odgrywają w procesie wychowania społecznego również organizacje młodzieżowe, głównie harcerstwo.

Słowa kluczowe: wychowanie społeczne; indywidualizm; kolektywizm; sprawiedliwość; rodzina; Kościół katolicki; szkoła; nauczyciel; programy szkolne.

\section{SOCIAL EDUCATION IN THE JACEK WORONIECKI'S POINT OF VIEW}

\section{SUMMARY}

Social education's issues were Jacek Woroniecki's particular interest. He was a scholar and practitioner, who, as a teacher and pastor, exerted influence on the formation of characters and attitudes of children and young people. The Polish Dominican also devoted a lot of space to this issue in his works.

Woroniecki was opposed to individualism and collectivism-doctrines that, in his opinion, overly interpreted human nature. The first of these - individualism - downplayed the social upbringing of people, recognizing that man as an egoist by nature will never be able to accept the moral norms and principles imposed on him by society. So, individualists believed that a man should first of all be the master of his lif - not looking at society and the rules of conduct binding in it. The second of these doctrines - collectivism - assumed that imposing norms of behavior on individuals in large social groups (e.g. nation or state) would certainly contribute to maintaining social order, even against the good of individual people.

The Polish Dominican believed that the fight against individualism and collectivism must consist in educating man for moral virtues, both individual and social. Thanks to them, man can function properly in society and develop his natural predispositions and inclinations, as well as live well and function as a fully free and autonomous person in his actions.

Woroniecki devoted a lot of space in his works to the virtue of justice, which by many of his modern thinkers was falsely conceived. This was the source of many social conflicts and misunderstandings. He also believed that one should return to the ancient and medieval (mainly scholastic and based on the St. Thomas Aquinas'works) concept of justice as a moral virtue, consisting in giving every man what was rightly due to him. Everyone should be brought up in this attitude; it is 
not possible to reduce fair proceedings only to observing the law established by the state. Every human being should, spontaneously and without any external coercion, take care of his own good and that of other people, doing it naturally, since childhood.

According to Woroniecki, people should be brought up to social life in the natural communities they need to function well: the family, the Catholic Church, and school, which due to the rapid development of science and education plays an increasingly important role in the modern world. In Woroniecki's opinion, the family should have a monogamous and lasting character, and its development and educational tasks should be supported by the state and its binding law. Also, the Catholic Church, which is an institution that enables the spiritual development of man, gives its community members the opportunity to cooperate and work together, and thus to grow up. It also teaches less and less often, but a valuable and dignified cultivation of the virtue of humility, as well as regularity and perseverance in the pursuit of good.

The school educates man thanks to teachers and educators who should be morally good and educated people, and who know well the child's psyche and the law of his moral, intellectual and physical development. Woroniecki attached great importance to the need for skilful education of students based on well-prepared school programs and properly selected reading material. Youth organizations, mainly scouts, also play an important role in social education.

Key words: social education; individualism; collectivism; justice; family; Catholic Church; school; teacher; school programs. 